\title{
Author Index Volume 29 (2009)
}

The issue number is given in front of the page numbers.

Anderson, R., Librarians and publishers in the eye of the format-migration storm

(4) $133-141$

Armbruster, C. and S. Hagenhoff, APE - Academic Publishing in Europe: Researchers, Librarians and Publishers

Armbruster, C., see Hagenhoff, S.

(4) $123-131$

Barden, B., see Harris, S.S.

Brase, J., A. Farquhar, A. Gastl, H. Gruttemeier, M. Heijne, A. Heller, A. Piguet, J. Rombouts, M. Sandfaer and I. Sens, Approach for a joint global registration agency for research data

Brindley, D.L.J., Challenges for Great Libraries in the Age of the Digital Native

Brooks, T.C., Organizing a research community with SPIRES: Where repositories, scientists and publishers meet

$(2,3) \quad 55-63$

(1) $45-52$

(1) $13-27$

(1) $3-12$

$(2,3) \quad 91-96$

Brown, D.J., International Council for Scientific and Technical Information (ICSTI) Annual Conference - Managing Data for Science

(4) $103-121$

de Kemp, A., Editorial

(1) $1-2$

de Kemp, A., Selected papers from the international conference Academic Publishing in Europe: The Impact of Publishing

$(2,3) \quad 53-54$

Evans, P., The New Deal - freedoms, experiments, sustainability. The road ahead

$(2,3) \quad 99-101$

Farquhar, A., see Brase, J.

(1) $13-27$

Gardner, J.A. and R.A. Kelly, The future is near: Universally usable mainstream on-line publishing

Gastl, A., see Brase, J.

Gruttemeier, H., see Brase, J.

$(2,3) \quad 97-98$

(1) $13-27$

(1) $13-27$

Hagenhoff, S. and C. Armbruster, Academic Publishing in Europe: The Impact of Publishing Hagenhoff, S., see Armbruster, C.

Harris, S.S., B. Barden, H.K. Walker and M.A. Reznek, Assessment of student learning behaviors to guide the integration of technology in curriculum reform

Heijne, M., see Brase, J.

Heller, A., see Brase, J.

$(2,3) \quad 55-63$

(4) $123-131$

(1) $45-52$

(1) $13-27$

(1) $13-27$

Jones, K.C., see Zyskind, A.

(1) $29-43$

Kelly, R.A., see Gardner, J.A.

$(2,3) \quad 97-98$

LaFaye Barker, A., see Zyskind, A.

(1) $29-43$ 
Piguet, A., see Brase, J.

(1) $13-27$

Pomerantz, K.L., see Zyskind, A.

(1) $29-43$

Ramjoué, C., Access to scientific information: European Commission initiatives

$(2,3) \quad 81-90$

Reznek, M.A., see Harris, S.S.

(1) $45-52$

Rombouts, J., see Brase, J.

(1) $13-27$

Sandfaer, M., see Brase, J.

Sens, I., see Brase, J.

(1) $13-27$

Studer, R., The Semantic Web. Enabling innovative approaches for handling information and services

(1) $13-27$

$(2,3) \quad 73-80$

Walker, H.K., see Harris, S.S.

Winckler, G., Universities in the 21 st century

(1) $45-52$

$(2,3) \quad 65-72$

Zyskind, A., K.C. Jones, K.L. Pomerantz and A. LaFaye Barker, Exploring the use of computer based patient education resources to enable diabetic patients from underserved populations to self-manage their disease

(1) 29- 43 